\title{
Issues of ICT Usage among Malaysian Secondary School English Teachers
}

\author{
Arumugam Raman ${ }^{1} \&$ Abdul Halim Mohamed ${ }^{1}$ \\ ${ }^{1}$ School of Education and Modern Languages, Universiti Utara Malaysia \\ Correspondence: Arumugam Raman, School of Education and Modern Languages, UUM, 06010 Sintok, Kedah, \\ Malaysia. Tel: 604-928-4852. E-mail: arumugam@uum.edu.my
}

Received: May 29, 2013 Accepted: June 30, 2013 Online Published: August 15, 2013

doi:10.5539/elt.v6n9p74 URL: http://dx.doi.org/10.5539/elt.v6n9p74

\begin{abstract}
This study explored on perception, usage and obstacles of using ICT in teaching English Language among secondary school English teachers. The advancement of technology has given a space for teachers to boost teaching and learning of English language in secondary schools. It is believed that integration of ICT could enhance quality of teaching and make learning very effective. This paper first examined on secondary school English teachers' perception about the integration of ICT in teaching English lessons. It is found that the majority of teachers have positive views about the integration of ICT in teaching English. Then, the study revealed about the usage level of ICT among secondary school English teachers. The findings showed that teachers are utilizing ICT equipments only for certain tasks such as finding for information and preparing PowerPoint presentations. They do not have much exposure about the other opportunities provided by ICT. Next, researchers identified the dominancy of obstacles faced by secondary school English teachers in ICT integration with English lessons. Finally, this study provides some implications of the study and recommendations which are useful for researchers to expand their study in this area. In addition, this study too provides information for teachers on the advantages of ICT. Therefore, teachers could make adjustment to their teaching methodology which may lead to effective ICT integrated teaching and learning of the English language.
\end{abstract}

Keywords: English language, English teachers, Information and Communication Technology (ICT), perception, obstacles, ICT integration

\section{Introduction}

The main aim of this study is to reveal the perception, usage and obstacles face by secondary school English teachers in integrating technology with English lessons in classroom. This study will be useful for policy makers to take into consideration the perception and usage level of ICT among English teachers in teaching English when planning ICT based curriculum or syllabus. Further, this survey will also be helpful for pre-service teachers to take into consideration the obstacles that they are going to face in teaching life and prepare themselves to make a better teacher.

According to Samuel \& Zaitun (2007) recent figures released by the Ministry of Education (2004) shows that 4,500 schools are already equipped with computer laboratories, 99,000 computer units and 4,600 servers. In addition, a total of 8,120 schools is connected to the broadband School-Net and a total of 97,000 laptops and 70,000 LCD projectors have been supplied to teachers teaching core subjects (Samuel \& Zaitun, 2007). However, there was a problem identified among secondary school English teachers during practicum which is the lack of integration of ICT in teaching English language. This area has been studied by many but the teachers' perception of ICT, their percentage of usage and dominancy of the obstacles they face are still questionable. Hence, the researcher would like to study about the English teachers' perception of integrating ICT in English lessons and the dominancy of obstacles which prevent them from using ICT in their teaching and learning process. This study would be very helpful for pre-service teachers to get prepared before stepping into the real world of teaching.

\subsection{Research Objectives}

The objectives of this research are as follows: 
1) To assess secondary school English teachers' perception towards integrating ICT in teaching English Language.

2) To find out the usage level of ICT among secondary school English Language teachers in teaching English Language.

3) To identify the dominancy of obstacles faced by secondary school English Language teachers in integrating ICT in teaching English Language.

\subsection{Theoretical/Conceptual Framework}

The model supporting this study is the Technological Pedagogical and Content Knowledge (TPACK) model (Figure 1). Teaching is a very multifaceted process and it requires educators with different kind of expert knowledge. In the English language classroom, the teaching and learning cannot be done with the textbook alone (Mishra and Koehler, 2006). The model clearly illustrates the knowledge that teachers need to understand in order to integrate technology effectively in their classrooms.

Teachers who exhibit best practices with technology are "creative, flexible, and adapt ways in which they navigate the constraints, affordances, and interactions within the TPACK framework (Mishra \& Koehler, 2008).

The authors have highlighted how the use of technology in the classroom has become a unique $21^{\text {st }}$ century pedagogical approach. The TPACK model has attempted to compile the main qualities of knowledge for the teachers so that they would be able to integrate the technology into their teaching and learning surroundings. The technological, pedagogical and content knowledge (TPACK) framework presents a way of thinking about effective technology integration, specific knowledge associated with integrating technology effectively into learning environments. Further, the revelation of Shulman's (1986) work on pedagogical content knowledge (PCK) has resulted in the ideas that teachers should possess knowledge related to both content and pedagogy, and that teacher education and in-service professional development programs should provide learning opportunities for teachers to develop these areas.

Figure 1 clearly shows the correlation between and among the three complex primary forms of knowledge. Based on Harris, Mishra \& Koehlar (2009), content knowledge is described as the knowledge teachers have about the subject matter that they teaches in the classroom. Next, pedagogical knowledge refers to the knowledge teachers have about the methods of teaching, managing classes and planning lessons. Technological knowledge is one of the most emphasized knowledge in this study and it can be defined as the knowledge teachers have about the integration of technology in lessons in order to conduct lessons effectively. The teachers should also have the knowledge of new technologies, so that they can adapt the technologies to their lessons.

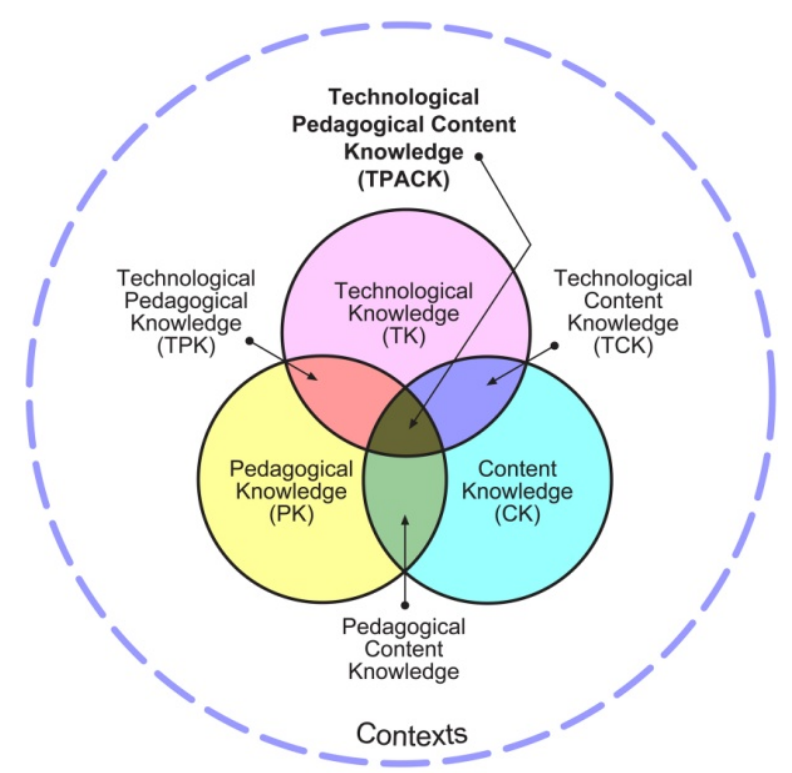

Figure 1. The TPACK Model (Mishra \& Matthew J. Koehler, 2006)

The emergence of three mentioned knowledges has produced new knowledge which teachers need to ensure their lessons are flexible. The first new knowledge is Technological Pedagogical Knowledge (TPK) where 
teachers change their way of teaching to new pedagogy that highlights the role of technology application in lessons. The second new knowledge known as Technological Content Knowledge (TCK) refers to the change in the subject matter as teachers have to teach their lessons with the support and application of technology. The third new knowledge is the Pedagogical Content Knowledge (PCK) which is defined as the knowledge of pedagogy that teachers should know such as ways of organizing, adapting and representing instructions in the classrooms. Overall, the TPACK model puts emphasis on the integration of content, pedagogy and technology to ensure the process of teaching and learning take place effectively.

\subsection{Literature Review}

According to Murphy and Greenwood (1998) ICT can be used to present information in new ways which help students understand more readily. It can give students the power to try different ideas and instill confidence in learners so that they are able to challenge themselves. Besides, ICT is also able to save money and time, which can eventually improve the use of the teacher's time. Therefore, teachers who are the designers of lessons should know the advantages of using ICT and play their role in integrating ICT into their daily English language classroom. Besides, based on Wyatt (1984), computers are seen as a tool which can make "worthwhile contribution to the teaching of English as second language".

Today, the Malaysian government has taken several steps in achieving the 'One Malaysia' concept where Malay, Chinese and Indians are being asked to see themselves as Malaysians. This is a great challenge and one of the ways to attain this is through education. In the ninth Malaysian plan which focused from the year 2006 until 2010, the government had allocated RM41 million, for educational purposes and this is the highest allocation in the social field. Hence, the government has been emphasizing and providing many facilities especially ICT tools to achieve the country's vision 2020. The vision 2020 plan has highlighted that the education system has to be transformed in order to produce generation with high technology knowledge. According to Raman (2010) educational technologies could make teaching easier for teachers and learning enjoyable for students. The education ministry believes that ICT could revolutionize education and provide better teaching and learning environment.

English language teachers' perception is very vital as it will determine the usage level of ICT in English classes and its impact on the students. The above statement is supported by Garthwait and Weller (2005) as they say that teachers' believe and perception of technology can determine the usage of it in the classroom. English is given importance by the Education Ministry compared to other subjects as it is a core subject in secondary schools and can be considered as a second language in our country. Perception is being emphasized because if English teachers have a negative perception on the use of ICT, then the dissemination of computer knowledge and effort of government in encouraging ICT integrated language teaching will be in vain. Therefore English teachers' perception about the usage of ICT in teaching English language is one of the key drivers which will determine the effectiveness of using ICT in English language classes.

According to Samuel and Zaiton (2006) English language standards have been deteriorating over the years and basic oral skills have been appalling due to lack of usage and reflective practice. English lessons that incorporate multimedia applications can exert powerful motivation and provide bored students with exciting new ways to learn. This shows that integration and utilization of ICT in teaching English Language among teachers may enhance students' English language competency and provide a positive learning environment. Look (2005) cited that a review of 219 studies on the use of technology in education consistently found that students in technology rich environments experienced positive effects on achievement in all subject areas. The usage level of ICT among teachers can be found through the survey that the researcher going to carry out and it will show the present scenario of ICT usage among English teachers. It will also determine whether ICT skills of English language teachers with existing infrastructure facilities are adequate to promote English language teaching and learning in English Language classes.

The use of ICT in language teaching gives emphasis to ensure the teaching and learning process to take place effectively in today's English Language classrooms. However, there are several obstacles that affect the frequency of the usage of ICT among English teachers and this study will draw out the dominating obstacles which affect ICT usage among English teachers. Khalid (2009) says that studying the obstacles to the use of ICT in education may assist educators to overcome these barriers and become successful technology adopters in the future. Besides, there are several obstacles found through many studies but the obstacles identified may vary based on different samples. Stolle (2008) had pointed out that the barriers faced by teachers are because of commitment towards printed materials and lack of knowledge and experience on the importance of ICT tools. 


\section{Method}

This study was carried out to collect data on Perception, usage and obstacles in using ICT in teaching English language among secondary school English teachers in semi-urban schools around Sungai Petani, Kedah. The process of the overall study took about three months which were from January 2012 until March 2012. Basically, this is a quantitative study and it was conducted by using a questionnaire which is convenient to collect data from teachers in various schools. The researcher will distribute questionnaires to 30 trained teachers from three secondary schools.

The schools selected for this study were Sekolah Menengah Kebangsaan Che Tom, Sekolah Menengah Kebangsaan Pinang Tunggal and Sekolah Menengah Kebangsaan Dato' Bijaya Setia. The researcher had visited these three schools before distributing questionnaires in order to obtain information regarding ICT facilities in the schools selected.

This is a quantitative research and it involves numerical representation which was based on the survey conducted in three schools. Creswell (1994) defines quantitative research as a type of research that explains a phenomena through the collection of numerical data which analyzed by using statistics. There are four types of quantitative research such as survey research, correlational research, experimental research and causal-comparative research. The researcher identified survey as the best method to answer the research questions of this study. This is because survey research measures the characteristics of the population sample with statistical precision by using questionnaire design and scientific sampling.

This quantitative study was conducted by using an adopted questionnaire designed by Gulbahar \& Guven (2008); Hutchison (2009). The reliability of the instrument is validated by the researchers and it is suitable for this study. The questionnaire consisted of two parts, where part A focuses on teacher sex, race and school while part B has three sections which are based on a Likert scale (1-5) and were used to extract information on three correlated areas. The items in section B were carefully chosen from the original questionnaire in order to suit the teaching context in Malaysia. The first section in part B consisted of 15 items regarding teachers' perception towards integrating ICT in teaching English lessons. In the second section of part B there are 15 items which measured on the usage of ICT among teachers in teaching English. Lastly, the third section composed of 15 items regarding the obstacles that teachers probably face in integrating and utilizing ICT in the process of teaching English language. The data gathered through the questionnaire was analyzed by using computer software used for survey authoring and deployment known as Statistical Package for the Social Sciences (SPSS) version 17.0 in order to get the accurate tabulation.

\section{Results}

The number of respondents for this study is 30 respondents who are in-service English language teachers from three secondary schools located around Kuala Muda Yan district in Sungai Petani, Kedah. Each respondent assigned a number called Identity Number (ID) which starts from 1 to 30 so that the data analyzing process is easier and systematic. The respondents consist of teachers from both genders which are male and female. There are about 9 male respondents and 21 female respondents approached for this study.

Besides, this study received respondents from different races such as Malay, Chinese and Indian. The three schools involved in this study are SMK Pinang Tunggal, SMK Che Tom and SMK Dato' Bijaya Setia. The number of respondents from the first school is 8 , second school is 10 and third school is 12 . The other personal details apart from gender, race and school are kept as confidential.

The analysis of the findings is done by going through each and every item used in both sections A and section B of the questionnaire.

The majority of the respondents are females (70\%) compared to males who are only $30 \%$. The proportions of the different gender show that females are the most dominant sex in the teaching profession in Malaysia.

Figure 2 below shows the mean score of overall respondents' responses from three different schools for all the items in the questionnaire. As we can see from the table, perception has higher score compare to usage and obstacle. This is an evident that majority of the teachers' perception about ICT integration English lessons are positive. The red bars which represent usage indicate fluctuation and it implies the existence of differences in the usage of ICT among the respondents. The researcher found that the same oscillation happens in usage is also applies to the third section of the study which is the dominance of obstacles faced by secondary school English Language teachers in integrating ICT in teaching English Language.

Table 2 points out the usage level of ICT among secondary school English Language teachers in teaching English Language. The usage level of ICT can be divided into two categories. The first category is the group 
with higher level which is above the neutral level whereas the second category is lower level which is below the neutral level. Most of the items from U16 to U30 show higher level of usage except for items such as U18 and U20 which represents a lower level of usage.

\section{Mean Score of the Respondents}

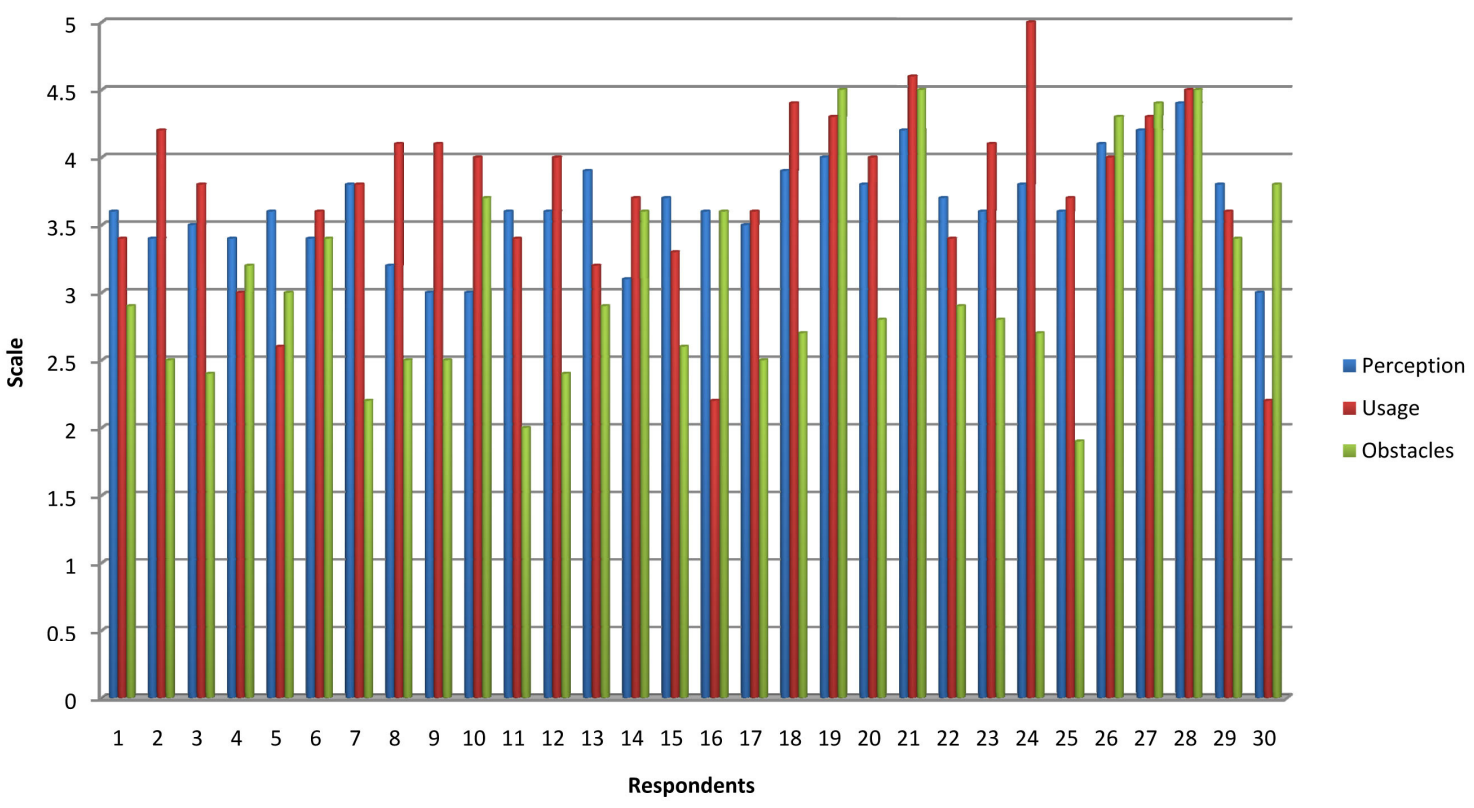

Figure 2. Mean score of the respondents for 3 major sections of the study

\subsection{Perception of English Teachers about Integrating ICT in Teaching English Language to Secondary School Students}

Table 1. Perceptions of secondary school English teachers about integrating ICT in teaching English language

\begin{tabular}{|c|c|c|c|c|c|c|}
\hline Items & Perceptions & $\begin{array}{l}\text { Strongly } \\
\text { Disagree } \\
(\%)\end{array}$ & $\begin{array}{l}\text { Disagree } \\
(\%)\end{array}$ & $\begin{array}{l}\text { Neutral } \\
(\%)\end{array}$ & $\begin{array}{l}\text { Agree } \\
(\%)\end{array}$ & $\begin{array}{l}\text { Strongly agree } \\
(\%)\end{array}$ \\
\hline P1 & $\begin{array}{l}\text { I don't use computers as much as } \\
\text { other resources (books, overhead } \\
\text { projectors etc.) for instructional }\end{array}$ & 10.0 & 33.3 & 13.3 & 33.3 & 10.0 \\
\hline $\mathrm{P} 2$ & $\begin{array}{l}\text { I know what to do for using } \\
\text { computers in instructional } \\
\text { environments. }\end{array}$ & 0 & 6.7 & 6.7 & 73.3 & 13.3 \\
\hline P3 & $\begin{array}{l}\text { I am aware of the opportunities that } \\
\text { computers offer. }\end{array}$ & 3.3 & 3.3 & 3.3 & 56.7 & 33.3 \\
\hline P4 & $\begin{array}{l}\text { I am not sure that I am } \\
\text { computer-literate for } \\
\text { computers in my classes. }\end{array}$ & 20.0 & 23.3 & 20.0 & 30.0 & 6.7 \\
\hline P5 & I don't want to use computers. & 36.7 & 36.7 & 6.7 & 20.0 & 0 \\
\hline P6 & $\begin{array}{l}\text { I think that I can use instructional } \\
\text { technologies in class activities } \\
\text { more effectively day by day. }\end{array}$ & 0 & 6.7 & 6.7 & 76.7 & 10.0 \\
\hline P7 & $\begin{array}{l}\text { I believe that tools like e-mail, } \\
\text { forum and chat will make } \\
\text { communication with my students } \\
\text { easv. }\end{array}$ & 0 & 20.0 & 6.7 & 50.0 & 23.3 \\
\hline P8 & $\begin{array}{l}\text { I think that technology supported } \\
\text { teaching makes learning more }\end{array}$ & 0 & 3.3 & 0 & 73.3 & 23.3 \\
\hline
\end{tabular}




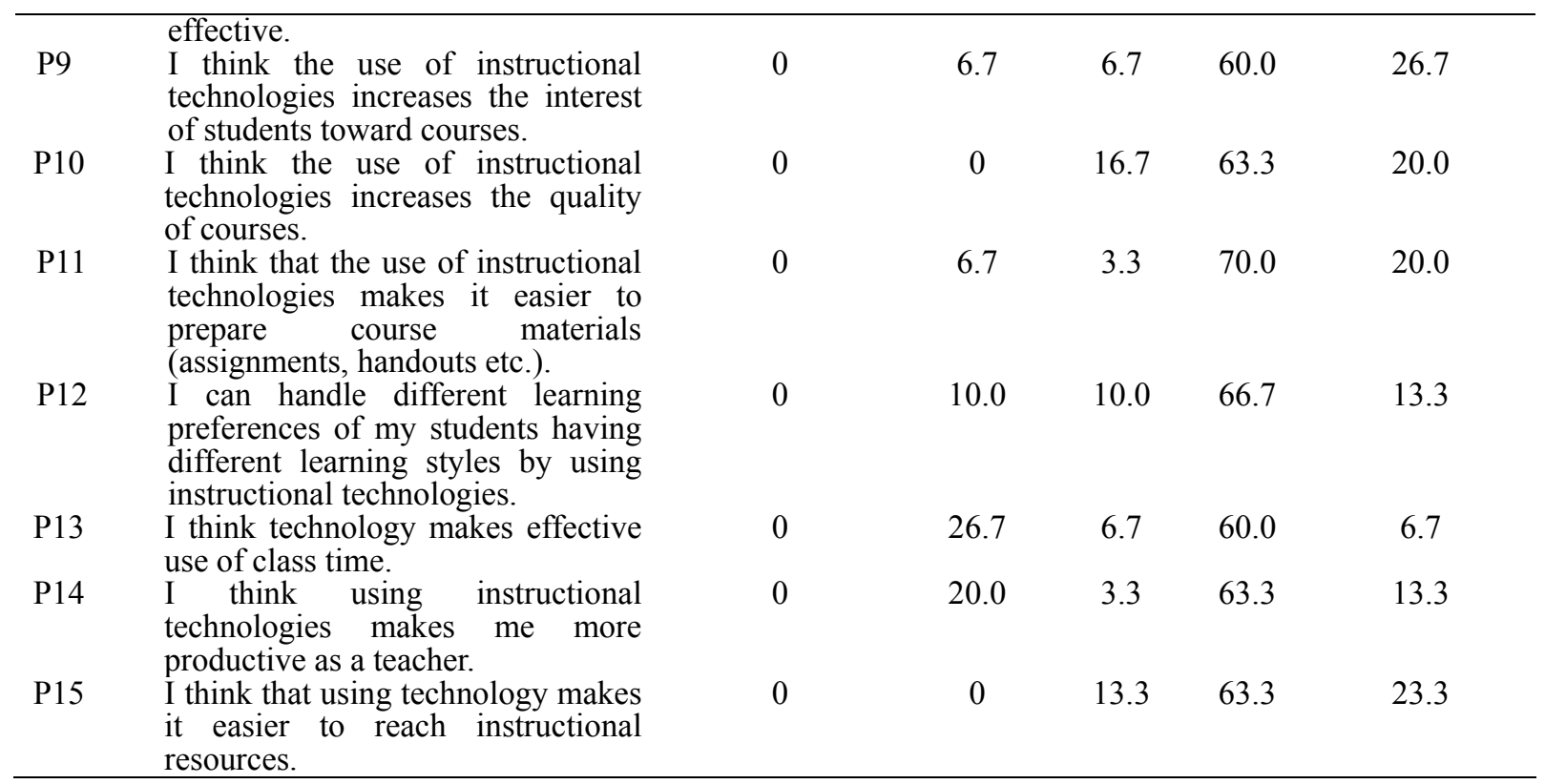

\subsection{Usage Level of ICT among Secondary School English Language Teachers in Teaching English Language}

Table 2. The usage level of ICT among secondary school English teachers in teaching English Language

\begin{tabular}{|c|c|c|c|c|c|c|}
\hline Items & Usage & $\begin{array}{l}\text { Strongly } \\
\text { Disagree } \\
(\%)\end{array}$ & $\begin{array}{l}\text { Disagree } \\
(\%)\end{array}$ & $\begin{array}{l}\text { Neutral } \\
(\%)\end{array}$ & $\begin{array}{l}\text { Agree } \\
(\%)\end{array}$ & $\begin{array}{l}\text { Strongly agree } \\
(\%)\end{array}$ \\
\hline U16 & $\begin{array}{l}\text { Playing educational games on a } \\
\text { CD-ROM. }\end{array}$ & 6.7 & 16.7 & 6.7 & 60.0 & 0.0 \\
\hline U17 & Sending email. & 0 & 3.3 & 3.3 & 76.7 & 16.7 \\
\hline U18 & $\begin{array}{l}\text { Publishing information on a Web } \\
\text { site or other chat tools. }\end{array}$ & 10.0 & 13.3 & 3.3 & 53.3 & 20.0 \\
\hline U19 & Gathering pictures online. & 0 & 6.7 & 3.3 & 60.0 & 30.0 \\
\hline $\mathrm{U} 20$ & Reading a book or story online. & 10.0 & 16.7 & 3.3 & 50.0 & 20.0 \\
\hline $\mathrm{U} 21$ & $\begin{array}{l}\text { Creating a multimedia presentation } \\
\text { (ex. PowerPoint). }\end{array}$ & 0 & 6.7 & 0 & 60.0 & 33.3 \\
\hline U22 & $\begin{array}{l}\text { Using reference sites online } \\
\text { (Ex.dictionary.com). }\end{array}$ & 3.3 & 10.0 & 6.7 & 53.3 & 26.7 \\
\hline $\mathrm{U} 23$ & $\begin{array}{l}\text { Communicating using } \text { Instant } \\
\text { Messenger (IM). }\end{array}$ & 6.7 & 26.7 & 16.7 & 33.3 & 16.7 \\
\hline $\mathrm{U} 24$ & $\begin{array}{l}\text { Formulating questions to research } \\
\text { online. }\end{array}$ & 3.3 & 23.3 & 20.0 & 43.3 & 0.0 \\
\hline $\mathrm{U} 25$ & Locating information onine. & 0 & 6.7 & 3.3 & 63.3 & 26.7 \\
\hline $\mathrm{U} 26$ & Evaluating information online. & 10.0 & 10.0 & 13.3 & 43.3 & 23.3 \\
\hline $\mathrm{U} 27$ & Synthesizing information online. & 6.7 & 10.0 & 13.3 & 43.3 & 26.7 \\
\hline $\mathrm{U} 28$ & Searching for information online. & 0 & 0 & 0 & 53.3 & 46.7 \\
\hline $\mathrm{U} 29$ & $\begin{array}{l}\text { Using specific search strategies to } \\
\text { search for information online. }\end{array}$ & 0 & 13.3 & 0 & 70.0 & 16.7 \\
\hline $\mathrm{U} 30$ & $\begin{array}{l}\text { Collaborating online with students } \\
\text { from other classes. }\end{array}$ & 10.0 & 23.3 & 13.3 & 36.7 & 16.7 \\
\hline
\end{tabular}

\subsection{Obstacles Face by Secondary School English Teachers in Integrating ICT in Teaching English Language}

The analysis of this section is divided into two categories. The first category is about negative items that decoded accordingly in SPSS. Table 3 shows that items in range from $\mathrm{O} 31$ to $\mathrm{O} 38$ consist of negative items with statements start with the word "don't". There are almost $60 \%$ of the respondents disagree with these negative 
statements. The item that $76.6 \%$ of the respondents disagree is item $\mathrm{O} 37$ which stated "I don't believe technology integration is useful", followed by items O33 (73.4\%), $\mathrm{O} 34$ and $\mathrm{O} 31(70 \%)$, and $\mathrm{O} 32$ (63.3\%).

Table 3. The dominancy of obstacles face by secondary school English teachers in integrating ICT in teaching English Language

\begin{tabular}{|c|c|c|c|c|c|c|}
\hline No. & Obstacles & $\begin{array}{l}\text { Strongly } \\
\text { Disagree } \\
(\%)\end{array}$ & $\begin{array}{l}\text { Disagree } \\
(\%)\end{array}$ & $\begin{array}{l}\text { Neutral } \\
(\%)\end{array}$ & $\begin{array}{l}\text { Agree } \\
(\%)\end{array}$ & $\begin{array}{l}\text { Strongly agree } \\
(\%)\end{array}$ \\
\hline $\mathrm{O} 31$ & I don't think technology is reliable. & 23.3 & 46.7 & 3.3 & 13.3 & 13.3 \\
\hline $\mathrm{O} 32$ & $\begin{array}{l}\text { I don't know how to incorporate } \\
\text { technology and still teach content } \\
\text { standards. }\end{array}$ & 20.0 & 43.3 & 6.7 & 20.0 & 10.0 \\
\hline $\mathrm{O} 33$ & $\begin{array}{l}\text { I don't know how to use } \\
\text { technology. }\end{array}$ & 26.7 & 46.7 & 6.7 & 3.3 & 16.7 \\
\hline $\mathrm{O} 34$ & $\begin{array}{l}\text { I don't think technology fits my } \\
\text { beliefs about learning. }\end{array}$ & 33.3 & 36.7 & 6.7 & 13.3 & 10.0 \\
\hline $\mathrm{O} 35$ & $\begin{array}{l}\text { I don't think I have enough time to } \\
\text { prepare for using technology. }\end{array}$ & 13.3 & 26.7 & 16.7 & 30.0 & 13.3 \\
\hline O36 & $\begin{array}{l}\text { I don't think I have time to } \\
\text { integrate technology because of the } \\
\text { amount of time required to prepare } \\
\text { students for high stakes testing. }\end{array}$ & 6.7 & 23.3 & 10.0 & 43.3 & 16.7 \\
\hline $\mathrm{O} 37$ & $\begin{array}{l}\text { I don't believe technology } \\
\text { integration is useful. }\end{array}$ & 33.3 & 43.3 & 10.0 & 6.7 & 6.7 \\
\hline $\mathrm{O} 38$ & $\begin{array}{l}\text { I don't know how skilled my } \\
\text { students are at using technology. }\end{array}$ & 10.0 & 33.3 & 3.3 & 46.7 & 6.7 \\
\hline $\mathrm{O} 39$ & Lack of access to technology. & 10.0 & 23.3 & 6.7 & 30.0 & 30.0 \\
\hline $\mathrm{O} 40$ & $\begin{array}{l}\text { Lack of incentives to use } \\
\text { technology. }\end{array}$ & 13.3 & 20.0 & 6.7 & 46.7 & 13.3 \\
\hline $\mathrm{O} 41$ & Lack of time during a class Period. & 0 & 16.7 & 3.3 & 56.7 & 23.3 \\
\hline $\mathrm{O} 42$ & Lack of technical support. & 0 & 10.0 & 3.3 & 63.3 & 23.3 \\
\hline $\mathrm{O} 43$ & $\begin{array}{l}\text { Lack of professional development } \\
\text { on how to integrate technology. }\end{array}$ & 0 & 16.7 & 3.3 & 60.0 & 20.0 \\
\hline O44 & Lack of funding. & 3.3 & 10.0 & 6.7 & 56.7 & 23.3 \\
\hline $\mathrm{O} 45$ & $\begin{array}{llll}\text { Lack of } & \text { support } & \text { from } \\
\text { administrators. } & & \\
\end{array}$ & 10.0 & 10.0 & 16.7 & 50.0 & 13.3 \\
\hline
\end{tabular}

\section{Discussion}

Basically, ICT has become an alternative especially for teachers in teaching English language. ICT undeniably gives benefits on students' attainments in learning English. English lessons delivered with ICT are able to produce successful lessons. Overall, this study investigated secondary school teachers' perceptions about the ICT integrated English lessons, their usage level of ICT and the dominancy of obstacles faced by teachers in integrating ICT in English teaching.

Based on the findings and discussions, it is found that both teachers and school administrators have their own role in promoting ICT integrated English teaching in schools. The majority of the teachers is having a positive perception about ICT integrated English lessons. However, teachers' usage level of ICT showed that teachers merely use ICT for finding information online, preparing PowerPoint presentations and reading. They do not realize about the advantages of other ICT applications.

In conclusion, teachers are encouraged to develop their ICT skills and think of more ICT integrated English lessons while schools are advised to provide better and sufficient ICT facilities to be utilized by English teachers. The cooperation between teachers and school administrative will produce more effective ICT integrated English lessons that could motivate students in learning the target language. 


\section{References}

Bee, T. L., \& Chia H. S. (2008). Exploring the extent of ICT adoption among secondary school teachers in Malaysia. International Journal of Computing and ICT Research [Online], 2(2). Retrieved December 29, 2012, from http://ijcir.org/volume2-number2/article3.pdf

Coiro, J., \& Dobbler, E. (2007). Exploring the online reading comprehension strategies used by sixth- grade skilled readers to search for and locate information on the Internet. Reading Research Quarterly, 42(2), 214-257. http://dx.doi.org/10.1598/RRQ.42.2.2

Creswell, J. W. (1994). Research design: Qualitative and quantitative approaches. Thousand Oaks: Sage Publication.

Cuban, L. (2001). Oversold and underused: Computers in the classroom. Cambridge, MA: Harvard University Press.

Cuban, L., Kirkpatrick, H., \& Peck, C. (2001). High access and low use of technologies in High school classrooms: Explaining an apparent paradox. American Educational Research Journal, 38(4), 813-834. http://dx.doi.org/10.3102/00028312038004813

Davies, C. (2007). Teaching Secondary English with ICT: What can technology do to English. New York.

Elia, A. (2007). Fables and ICT: Intercultural Communication and E-Language Teaching. Retrieved January 14, 2012, from http://www.immi.se/intercultural/nr14/elia.htm

Ertmer, P. A., Gopalakrishnan, S., \& Ross, E. M. (2001). Technology-using teachers: Comparing perceptions of exemplary technology use to best practice. Journal of Research on Technology in Education, 33(5).

Garthwait, A., \& Weller, H. (2005). A year in the life: Two seventh grade teachers implement one-to-onecomputing. Journal of Research on Technology in Education, 37(4), 361-377.

Gulbahar, Y., \& Guven, I. (2008). A Survey on ICT Usage and the Perceptions of Social Studies Teachers in Turkey. Educational Technology \& Society, 11(3), 37-51. Retrieved on December 14, 2012, from http://www.ifets.info/journals/11_3/4.pdf

Harris, J., Mishra, P., \& Koehler, M. (2009). Teachers' technological pedagogical content knowledge and learning activity types: Curriculum-based technology integration reframed. Journal of Research on Technology in Education, 41(4), 393-416.

Koehler, M., \& Mishra, P. (2008). Introducing technological pedagogical content knowledge. Paper presented at the Annual meeting of the American Education Research Association, New York City, New York. Retrieved on January 19, 2008, from http://punya.educ.msu.edu/presentations/AERA2008/MishraKoehler_AERA2008.pdf

Lanni, D. (2001). The Rationale: ICT in Language Teaching in 6 Points. Retrieved January, 2012, from http://www.itiscannizzaro.net/Ianni/articles/rationale.htm

Look, D. (2005). Impact of Technology on Education. Discussion paper in PUSD Excellence Committee. $\begin{array}{llllll}\text { December } 2005 . & \text { January } & \text { 15, 2012, } & \text { from }\end{array}$ http://pleasanton.k12.ca.us/Superintendent/Downloads/Technology.pdf

Ministry of Education (MOE). (2004). The Development of Education National Report of Malaysia. Retrieved January 5, 2012, from http://www.ibe.unesco.org/International/ICE47/English/Natreps/reports/malaysia.pdf

Mishra, P., \& Koehler, M. J. (2006). Technological pedagogical content knowledge: A framework for teacher $\begin{array}{llll}\text { knowledge. Teachers } & \text { College } & \text { Record, } & \text { 108(6), }\end{array}$ http://dx.doi.org/10.1111/j.1467-9620.2006.00684.x

Murphy, C., \& Greenwood, L. (1998). Effective Integration of Information and Communications Technology in Teacher Education. Journal of Information Technology for Teacher Education, 7(3), 413-429. http://dx.doi.org/10.1080/14759399800200039

Raman, A. (2010). ICT in Education. Kedah: Universiti Utara Malaysia Press.

Samuel, R. J., \& Zaiton, A. (2006). The utilization and integration of ICT tools in promoting English language teaching and learning: Reflections from English option teachers in Kuala Langat District, Malaysia. International Journal of Education and Development using Information and Communication Technology (IJEDICT), 2(2), 23-34.

Samuel, R. J., \& Zaitun, A. B (2007). Do teachers have adequate ICT resources and the right ICT skills in 
integrating ICT tools in the teaching and learning of English Language in Malaysian schools? The electronic journal on information systems in developing Countries (EJISDC), 29(2), 1-15. Retrieved January 18, 2012 , from http://www.ejisdc.org/ojs2/index.php/ejisdc/article/viewFile/283/195

Stolle, E. (2008). Teachers, literacy, \& technology: Tensions, complexities, conceptualizations \& practice, reading conference yearbook. Milwaukee: WI.

Wyatt, H. D. (1984). Computers and ESL: Language in Education Theory and Practice. Englewood chits: Prentice hall.

\section{Copyrights}

Copyright for this article is retained by the author(s), with first publication rights granted to the journal.

This is an open-access article distributed under the terms and conditions of the Creative Commons Attribution license (http://creativecommons.org/licenses/by/3.0/). 